ORNL --6636

DE91 005628

ORNL-6636

Energy Division

\title{
NAVY MOBILITY FUELS FORECASTING SYSTEM PHASE VI REPORT: THE POTENTIAL IMPACTS OF A WORST-CASE MILITARY CONFLICT ON WORLD PETROLEUM AVAILABILITY
}

\author{
Principal Investigators \\ R. Lee \\ S. Das \\ P. N. Leiby \\ ORNL Program Manager \\ R. M. Davis \\ DATE PUBLISHED: January 1991
}

Report Prepared for

Navy Energy \& Natural Resources Office

Office of Naval Research

Department of the Navy

Navy Program Manager

A. Roberts

Operated by

OAK RIDGE NATIONAL LABORATORY

Oak Ridge, T'ennessee 37831

managed by

MAKTIN MARIETTA ENERGY SYSTEMS, INC.

for the

U.S. DEPARTMENT OF ENERGY

under contract DE-AC05-84OR21400 


\section{CONTENTS}

ACRONYMS AND ABBREVIATIONS $\ldots \ldots \ldots \ldots \ldots \ldots \ldots \ldots \ldots \ldots \ldots \ldots \ldots$

ACKNOWLEDGEMENTS $\ldots \ldots \ldots \ldots \ldots \ldots \ldots \ldots \ldots \ldots \ldots \ldots \ldots \ldots \ldots \ldots \ldots \ldots \ldots$

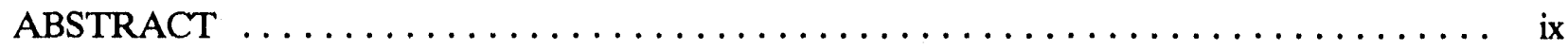

EXECUTIVE SUMMARY $\ldots \ldots \ldots \ldots \ldots \ldots \ldots \ldots \ldots \ldots \ldots \ldots \ldots \ldots \ldots \ldots$

1. INTRODUCTION $\ldots \ldots \ldots \ldots \ldots \ldots \ldots \ldots \ldots \ldots \ldots \ldots \ldots \ldots \ldots \ldots$

2. DESCRIPTION OF MILITARY DISRUPTION SCENARIO $\ldots \ldots \ldots \ldots \ldots \ldots$

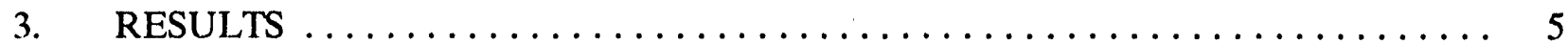

3.1 WORLD OIL SUPPLY AND DEMAND $\ldots \ldots \ldots \ldots \ldots \ldots \ldots \ldots \ldots \ldots$

3.2 REGIONAL OIL SUPPLY AND DEMAND BALANCE $\ldots \ldots \ldots \ldots \ldots \ldots \ldots$

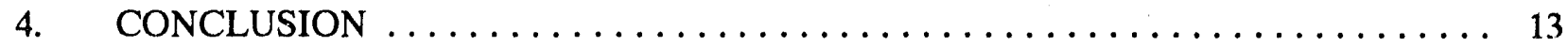

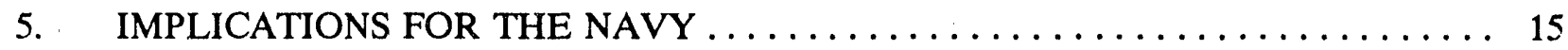

REFERENCES $\ldots \ldots \ldots \ldots \ldots \ldots \ldots \ldots \ldots \ldots \ldots \ldots \ldots \ldots \ldots \ldots \ldots \ldots \ldots \ldots$

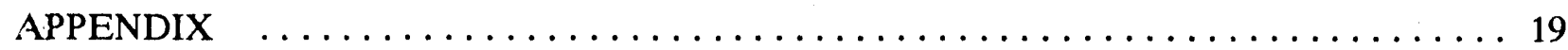




\section{ACRONYMS AND ABBREVIATIONS}

BAU Business-As-Usual

CPE Centrally Planned Economies

DIS Disruption Impact Simulator

DOD Department of Defense

DOE Department of Energy

DON Department of Navy

EIA Energy Information Administration

MBD Thousand barrels per day

MMBD Million barrels per day

NATO North Atlantic Treaty Organization

OECD Organization for Economic Cooperation and Development

OMS Oil Market Simulation

OPEC Organization of Petroleum Exporting Countries

ORNL Oak Ridge National Laboratory

PADD Petroleum Administration for Defense District

PAL Petroleum Allocation

SPR Strategic Petroleum Reserve 


\section{ACKNOWLEDGEMENTS}

Throughout the development and application of the Navy Mobility Fuels Forecasting System, technical guidance and collaboration have been received from the Navy Energy \& Natural Resources Office, the Naval Air Propulsion Center, and the David Taylor Naval Ship Research and Development Center. Technical support, data resources and access to the principal models used in the analysis have been furnished by the staff of the Energy Information Administration, Department of Energy. Steve Cohn and Tom Wilson of ORINL assisted in data preparation. Virginia Bolinger, Teresa Ault, and Pam Witcher did a masterful job on editing the manuscript. The report benefitted greatly from comments on earlier drafts that were provided by Dick Davis, Jerry Hadder, Pat Hu, and Anthony Turhollow of ORNL; and particularly by Buck Nowack of the Naval Air Propulsion Center. The valuable contributions of these individuals and organizations are gratefully acknowledged. 


\title{
THE POTENTIAL IMPACTS OF A WORST-CASE MILITARY CONFLICT ON WORLD PETROLEUM AVAILABILITY
}

\begin{abstract}
A major Middle East and European military confrontation would cause an extremely large disruption in the supply of oil worldwide. There would be imbalances between oil supply and demand. These imbalances can only be solved by rationing and by military actions to ensure an adequate flow of crude oil and products.
\end{abstract}




\title{
THE POTENTIAL IMPACTS OF A WORST-CASE MILITARY CONFLICT ON WORLD PETROLEUM AVAILABILITY
}

\author{
EXECUTIVE SUMMARY
}

This report considers the impact of an extremely severe military confrontation and oil market disruption on the availability of petroleum products worldwide. Under a worst-case scenario, supply would significantly decline--by over 20 million barrels per day worldwide, especially with the likelihood of naval hostilities. There would be large imbalances in the supply and demand for petroleum products. Available supply would not meet demand, even taking into account higher prices and greatly reduced civilian demand. Additional reductions in demand in the form of rationing would be expected, possibly on the U.S. West Coast, Scandinavia, Venezuela, Asian Exporters and Iran. Additional sources of supply would also have to be found to meet European demand. A major problem is in ensuring the safe passage of crude oil, from the Norwegian North Sea to European refineries, and especially the safe passage of products to Europe from the U.S. and Norway. Great quantities of liquid gases, gasoline, distillates, and residual fuel would have to be shipped irom the U. S. Gulf and East Coasts to Europe. 


\section{INTRODUCTION}

A major European military confrontation and an extreme disruption in the supply of oil from the Middle East would likely result in a worst-case scenario for the world oil market. Although very unlikely, the possibility of such events in the long-run is highly uncertain and such scenarios should be studied as part of any long-range contingency planning. This paper describes an experiment to estimate the imbalances that may result between regional oil supply and demand in the world in such a worst-case scenario. Many previcus papers and reports have considered the impacts of major disruptions in the supply of oil on the availability and quality of petroleum products. ${ }^{1}$ Other studies have discussed oil disruptions, vulnerability, and security. ${ }^{2}$

One of the most severe scenarios considered in past studies was a hypothetical disruption in which Persian Gulf exports were entirely curtailed, and in which North Sea production was reduced by $40 \%$, causing the overall reduction in the world supply of oil to be 16 million barrels per day (MMBD). ${ }^{3}$ Nevertheless, there was an economic solution to the disruption; there was an equilibrium between the supply and demand for products. That is, the demand for products in the world was met, without any shortages. The disruption did not seem "crippling", either in the sense of military needs going unsatisfied or in terms of the civilian sector requiring rationing or price controls. In some ways, this finding seemed surprising because the scenario included not just a severe disruption in oil supply but a large-scale military mobilization as well. To investigate this surprising result more closely, our study developed a more detailed military disruption scenario than the one in Das et al. (1988b).

${ }^{1}$ Refer to Buck (1973); Cutler (1985, 1986a, 1986b, 1987); Das et al. (1988a, 1988b); EIA (1989); Hadder et al. (1988a, 1988b, 1989); Leiby and Lee (1988); and Mawn (1988).

${ }^{2}$ Refer to Curlee (1982); Curlee and Reister (1989); Horwich and Weimer (1984, 1988); and US DOE (1987). Several modeling approaches have been suggested by Curlee et al. (1988); Das et al. (1988b); Leiby and Lee (1988); and Reister (1987).

${ }^{3}$ Refer to Das et al. (1988b) for additional details. 


\section{DESCRIPTION OF MILITARY DISRUPTION SCENARIO}

The military disruption is assumed to occur in the year 1995. The disruption is defined relative to the projected business-as-usual (BAU) conditions in 1995, as developed in Das et al. (1988b). This BAU projection was based on the most recent official Department of Energy/Energy Information Administration (DOE/EIA) mid-case forecast available at the beginning of that study. Additional detail was gathered from the most recent officially documented DOE models, including Oil Market Simulation (OMS), Disruption Impact Simulator (DIS), and the 1990 Petroleum Allocation (PAL) Model BAU case.

In its study of a military disruption scenario, Das et al. (1988b) did not consider the effect of naval hostilities on the flow of petrcleum. This current study, on the other hand, assumed that extensive military hostilities would lead to massive naval engagements in the North Sea and Mediterranean Sea. The engagements would involve enemy naval vessels, aircraft, and mines attacking fuel supply vessels going into Europe. Enemy activities were assumed to be targeted on incoming flows and a worst-case situation was considered, with $37 \%$ of the incoming flows being cut (Buck et al., 1973). In effect, enemy ships and aircraft reduced the incoming flow of crude oil by $37 \%$ and products by $23 \%$ of what they would have been if such flows were free to occur.

In addition to the $37 \%$ curtailment of incoming flows to Europe, it was also assumed that $10 \%$ of any outgoing crude and product flows from Europe were interrupted. It was further assumed that $10 \%$ of the crude flows to and from the Asia-Pacific and Indian Ocean regions were eliminated. The idea behind this assumption was that naval and air action sank many oil tankers; and, for those that remained, enemy action made safe passage more difficult and time-consuming, thus further reducing the flow of oil. ${ }^{4}$

It was assumed that there would be: (a) maximum use of strategic stocks, including those in all OECD countries; (b) increased demand by the military and by the defense industrial base; (c) the use of military stocks; and (d) lost imports of Soviet natural gas into Europe. The scenario is summarized in Table 1. As indicated in Table 1, the total "shortfall" (i.e. the net reduction in supply relative to the BAU) for the Military Disruption was estimated to be $20.3 \mathrm{MMBD}$, about $40 \%$ of the BAU supply.

\footnotetext{
${ }^{4}$ Because of the physical nature of the interdiction, it was assumed that the disrupted flows would not be re-directed to other regions. Instead, there would be a limit to the volume of flows. The reduction in product flows was assumed to be $9 \%$ instead of $10 \%$, since only $90 \%$ of the crude will be available for refinery operations.
} 
OPEC Disrupted Countries

Algeria

Iran

Iraq

Kuwait

Libya

Saudi Arabia

UAE

OPEC Crude and Product

Export Disrupted

North Sea Crude Output Disrupted

Flows Disrupted by Naval Actions: $37 \%$ of crude (23\% product) flows into Europe; and $10 \%$ of crude ( $9 \%$ product) flows out of Europe, in Indian Ocean, and South China Sea

(a) Volume Crude Flows Disrupted

(b) Total Product Mows Disrupted

Centrally-planned Economics

Net Exports Disrupted

Undisrupted OPEC Surge Production

(Ecuador, Venezueld, Nigeria)

"Inventory Demand" (Used as Proxy for

Foreign (Japan) SPR Draw

Militaıy Demand Increase

U.S. Military

NATO European Military

Non-NATO Military

U.S. Defense Industrial Base

European Defense Industrial Base

U.S. Military Stock Draw

European Military Stock Draw

* Components may not sum to total due to independent rounding. 


\section{RESULTS}

We focus on the models' results that relate to the reductions in world oil supply and demand, and to regional supply-demand imbalances. These balances have implications for (a) the possibility of rationing and other non-market measures to reduce demand, (b) special trade provisions and/or naval action to increase the supply of key exports, and (c) the general availability of fuels to meet both civilian and military demand.

\subsection{WORLD OIL SUPPLY AND DEMAND}

The OMS and DIS Models were used to forecast petroleum supply and demand in six regions in the world: United States, Japan, Western Europe, Canada, OPEC, and Other Countries. Table 2 shows the forecasted petroleum supply and demand in the six regions for the BAU scenario and for the Military Disruption. The forecasts were subdivided to provide estimates of crude oil supply and demand in the 33 regions used in the PAL Model.

The net reduction in supply of 20.3 MMBD caused a reduction in worldwide demand of 15.5 MMBD. Production increased in several countries in remonse to much higher oil prices. The increased military demand also caused price to increase. The price increase, as well as the physical interruption of oil flows, resulted in a sharp decline in civilian consumption. Traditional non-major petroleum consumers, particularly developing countries in Asia which are grouped as "Other Countries" in Table 2, were the most affected by the disruption. Petroleum demand in this region decreased $40.6 \%$ compared to demand in the BAU scenario. Also, a significant reduction in petroleum demand occurred in Western Europe, 31.8\% lower than in the BAU scenario. This decrease reflected the reduction in imports due to the disruption of flows by naval actions.

Of course, the greatest reduction in supply (i.e., production) occurre ${ }^{-}$in OPEC. Total crude supply fell in this region by $71.5 \%$ compared to the BAU scenario. The supply from "Other Countries" declined by $9.2 \%$ compared to the BAU scenario. A 0.1 MMBD reduction in the United States domestic crude supply was due to the disruption in its flows; much of the exports of products from the U.S. to Europe were no longer reaching Europe.

\subsection{REGIONAL OIL SUPPLY AND DEMAND BALANCE}

The PAL Model was used to obtain the supply and demand balance for 33 regions in the world. The appendix contains the definition of these $33 \mathrm{PAL}$ regions. In PAL, crude and refined product distribution are calculated so as to minimize the total cost of crude supply, crude and product transportation, and refining. Historical trading patterns are taken into account in the model, but cannot be replicated given the available crude supplies.

In the Pal Model, refining activities in each region depend on its refinery configuration. For a given configuration, a yield or mix of end-products is associated with each crude or slate of crudes processed in each region. Thus, regional refinery configurations play an important role in the model in achieving an interregional balance between supply and demand. Because of a disruption, the 


\begin{tabular}{|c|c|c|}
\hline \multicolumn{3}{|c|}{$\begin{array}{l}\text { Table 2. World oil demand for BAU } \\
\text { and Military Disruption scenarios }\end{array}$} \\
\hline & $\mathrm{BAU}$ & $\begin{array}{c}\text { Military } \\
\text { Disruption }\end{array}$ \\
\hline \multicolumn{3}{|l|}{ Demand (MMBD) } \\
\hline United States & 16.8 & 12.0 \\
\hline Canada & 1.7 & 1.1 \\
\hline Japan & 4.6 & 2.8 \\
\hline Western Europe & 12.6 & 8.6 \\
\hline OPEC & 4.2 & 4.2 \\
\hline Other Countries & 10.6 & 6.3 \\
\hline Total Free World & 50.5 & 35.0 \\
\hline \multicolumn{3}{|l|}{ Praduction (MMBD) } \\
\hline United States & 8.3 & 8.4 \\
\hline Canada & 1.6 & 1.6 \\
\hline Western Europe & 3.5 & 2.2 \\
\hline Other Countries & 9.8 & 8.9 \\
\hline CPE Net Exports & 0.9 & 0.0 \\
\hline Total Non-OPEC (excluding SPRs) & 24.1 & 21.1 \\
\hline U.S. SPR & 0.0 & 4.5 \\
\hline Japan SPR & 0.0 & 0.9 \\
\hline Other OECD SPR & 0.0 & 1.0 \\
\hline OPEC & 26.3 & 7.5 \\
\hline Total Free World & 50.5 & 35.0 \\
\hline
\end{tabular}


appropriate types of crudes may be unavailable to particular refineries, thereby resulting in less than desirable yields of certain products.

In the Military Disruption, supply and demand projections were obtained for each of the 6 categories of products in each ji the 33 regions, by disaggregating the DIS Model's estimates of the projections at the aggregate scale. Additional crude and product flow constraints were input to the PAL Model in order to depict naval interdiction. Because of these constraiats, a feasible PAL solution was obtained only after rationing was imposed in certain regions. ${ }^{5}$

There were four regions -- the U.S. West Coast, Scandinavia, Venezuela/Ecuador, and Asian Exporters -- which were unable to attain a supply-demand equilibrium even with an additional $30 \%$ reduction in demand imposed by rationing. To attain a world supply-demand equilibrium, the exports of products from the U.S. West Coast had to exceed the previously estimated maximum levels. Also, petroleum demand in Venezuela/Ecuador and in the Asian Exporter countries had to be reduced by $33 \%$. The limit on Scandinavian crude exports was also increased in order to attain a supplydemand equilibrium.

The following paragraphs discuss in detail these supply-demand imbalances, that were forecasted to result from the given supply, demand, crude, and product flow constraints that were projected to occur during the Military Disruption. The imbalances are measured in terms of the changes (both in absolute and in percentage terms) in demand, crude flows and product flows that would be required from the original input values (that gave the infeasible solution) in order to give a feasible supply and demand balance.

Regional Demand: Table 3 gives the estimates of petroleum demand in each of the PAL Model's regions for the BAU and the Military Disruption. The fourth and fifth column in this tabie show the further reductions in demand (in absolute and in percentage terms respectively) that would be required during the Military Disruption compared to demand if the oil market was left solely to market forces, without government intervention. ${ }^{6}$ The last two columns show the percentage reductions in demand during the Military Disruptions relative to the BAU (for both the original input-value for demand, i.e. free-market demand, and for demand after the reduction computed in the PAL Model, i.c. the reduction from government intervention).

${ }^{5}$ The PAL Model is a linear programming model. A "feasible" solution means that demands for crude oil and refined products are satisfied by available supplies, without violating certain limitations (i.e., constraints) on the capabilities of the transportation networks and refineries. The given supply, demand, crude, and product flow constraints that were projected to occur during the Military Disruption resulted in violations of around twenty-five constraints to obtain a feasible PAL supplydemand equilibrium solution. Most of these violations were in crude and product flow constraints; additional crude and product flows were required in order to satisfy regional demand. In order to obtain a computationally feasible solution, regional crude oil demand was allowed to decrease by as much as $30 \%$ of its original input crude oil demand. Demand reductions of $10 \%, 20 \%$, and $25 \%$ were tried; but the number of violations in the constraints decreased significantly only when regional demands were allowed to decrease by up to $30 \%$ of their original input values. The purpose of this calculation was to spread the effect of the disruption across all regions.

${ }^{6}$ This reduction is done in the PAL Model: if supply does not meet demand, then PAL reduces demand beyond the reductions already calculated by the DIS Model. 


\begin{tabular}{|c|c|c|c|c|c|c|}
\hline \multirow{2}{*}{$\begin{array}{l}\text { Regions } \\
\text { (with PAL. Designations) }\end{array}$} & \multirow[b]{2}{*}{ BAU } & \multicolumn{3}{|c|}{ Military Disruption } & \multicolumn{2}{|c|}{ 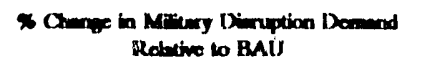 } \\
\hline & & $\begin{array}{l}\text { Input Value } \\
\text { Reflecting Proc } \\
\text { Martet }\end{array}$ & $\begin{array}{l}\text { Change To Have } \\
\text { Suppty in } \\
\text { Enuilibrium With } \\
\text { Demand }\end{array}$ & $\times$ onmere & 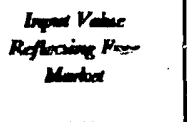 & 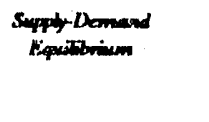 \\
\hline East Coast & 5403 & 3872 & & $a 0 x$ & $-2 \operatorname{sen} 3$ & .22836 \\
\hline Gulf Coast & $842 \%$ & 5966 & & $20 \%$ & -22004 & $-29.0 \%$ \\
\hline West Coast & 2671 & 1914 & .240 & $-125 x$ & $-283 \%$ & $-37.3 \%$ \\
\hline United States & 16500 & $117 m$ & .240 & $-20 \%$ & $-207 \%$ & $-301 \%$ \\
\hline Puerto Rion/Virgin Islands (U) & 300 & 215 & & aox & $.2203 \%$ & $-22 \pi 3 \%$ \\
\hline Canada (C) & 1700 & 1059 & & $20 x$ & $-37.7 \%$ & $-37.7 \%$ \\
\hline Japin $(J)$ & 4600 & 2844 & & $a x$ & $-3 \operatorname{sen}$ & $-3 R 2 x$ \\
\hline Australia/New Zealund (A) & 800 & 470 & & $0.0 \%$ & -11.35 & $-11.3 \%$ \\
\hline Scandinavia (i) & 828 & 574 & .102 & $-17.8 \times$ & -31 L & $-a 7 \pi$ \\
\hline Unired Kingdom/reland (2) & $17 \pi 9$ & 1219 & & a.on & $-31.5 \pi$ & $-315 \%$ \\
\hline BenelL.M. & 1366 & 936 & & aox & $-31.5 *$ & $-315 x$ \\
\hline West Germany (4) & 2500 & 1713 & & $20 \%$ & $.315 \%$ & -31.546 \\
\hline France (5) & 2000 & 1370 & & $\cos$ & $-31.5 \%$ & $-36.5 \%$ \\
\hline Austria/switzertand (6) & 50.3 & 344 & & $0.0 \%$ & $-3 L 5 x$ & $-31.5 \%$ \\
\hline Spain/Porugal (7) & 1188 & 814 & & aos & $-315 x$ & $-31.5 \%$ \\
\hline !laty $(8)$ & 1800 & 1233 & & $20 x$ & $-315 \%$ & $-31.5 \%$ \\
\hline (ireece/Turtey (9) & 627 & $4 ., 00$ & & $0.0 \%$ & $-314 \pi$ & $-31.4 \%$ \\
\hline V'enezuela/licuador (V) & $\$ 29$ & $5 x$ & .149 & $-282 x$ & $a 0 x$ & $-281 \%$ \\
\hline i.jbya/Aigeria (1.) & .341 & 341 & -1 & asts & $-a x$ & $0.3 x$ \\
\hline Nigeria/Gabon (N) & 342 & 342 & & $0.0 \%$ & $a 0 x$ & $0.0 \%$ \\
\hline Indonesia (1) & 607 & 607 & .13 & $-21 \%$ & $a 0 x$ & $-21 \%$ \\
\hline $\operatorname{Iran}(R)$ & 895 & 89. & .212 & $-2.7 \%$ & $\operatorname{nox}$ & $.28 .7 \%$ \\
\hline Persian Gull (P) & 1,37 & 1487 & .37 & $-25 x$ & $\operatorname{ans}$ & $-25 \%$ \\
\hline Caribbean $(\mathrm{K})$ & 30,5 & 182 & .55 & $-302 x$ & $-\sin \pi$ & $-58.3 \%$ \\
\hline Mexico (M) & 1564 & 933 & -6 & $a c k$ & $-10+4$ & $107 \%$ \\
\hline [(x)liviaPeru (B) & 868 & 585 & .27 & ect & $-326 \%$ & $-35.7 \%$ \\
\hline FgyptSyria/Bahrain (O) & 653 & 389 & & $00 \%$ & 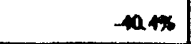 & $-40+x$ \\
\hline Ang Va/Congo/Zaire $(O)$ & 39 & 23 & .7 & $-304 \pi$ & $-11.0 \%$ & $-59.0 \%$ \\
\hline Asian Esporters $(Y)$ & 896 & $\$ 34$ & .176 & $.32 .0 \%$ & $-\infty<x$ & $600 \pi$ \\
\hline Other Latin America (S) & 1635 & 907 & & $a 0 x$ & $4.5 \%$ & $-4.5 \%$ \\
\hline Other Africa ifi) & 944 & 563 & & a.ox & +204 & $-104 \%$ \\
\hline Other Asia (X) & 2005 & 1726 & & a.d & $-404 \%$ & $-404 \%$ \\
\hline TOTAL & 50500 & 35036 & .1025 & $-29 \%$ & $-306 x$ & $-32.7 \%$ \\
\hline
\end{tabular}


An additional :eduction of $1 \mathrm{M} \mathrm{MMBD}$, or $2.9 \%$ of the total DIS world oil demand estimate of 35 MIMBD, is projected to occur because of incompatibilities between the particular mix of crude available during the Military Disruption, and the refinery capabilities. This reducticn in demand occurred in 12 of the 33 PAL re rions. The most notable regions were: U.S. West Coast, Scandinavia, Venezuela/Ecuador, Iran, and Asian Exp,orters where reductions in demand would be more than 100 MBD below the reductions calculated in the DIS Model. The U.S. West Coast demand would decrease by $37.3 \%$ compared to the $\mathrm{BAU}$, while in the other two U.S. regions the reduction in demand would be around $28 \%$. However, additional products were exported from the U.S. West Coast, the largest share contributed by liquid gases. Similarly, most of the other 11 regions with further reductions in their own consumption also cxported more crudes and products.

Regional Crude Exports: Table 4 gives estimates of crude oil exports during the Military Disruption scenario. The format of this table is similar to that in Table 3. Positive numbers in these columns indicate the amount of crude which may not flow due to the physical interdictions during the Military Disruption, but which are needed to maintain a supply-demand equilibrium.

During the Millitary Disruption, world crude oil exports would be reduced by $76.3 \%$ compared to the BAU. The Caribbean was the only region where the reduction in crude oil exports would be substantial (i.e., $72.2 \%$ of the BAU), other than the most severely disrupted regions such as OPEC and the United Kingdom/Ireland. Crudes that are available may be incompatible with refineries' configurations. These mismatches caused an additional $8 \%$ reduction in crude oil exports. Most of these reductions occurred in Nigeria/Gabon, Caribbean, and Asian Exporters.

For European and U.S. demands to be met, regional crude exports would have to increase from Scandinavia, Mexico, and Bolivia/Peru beyond those predicted during the Military Disruption. Scandinavia becomes a crude oil exporter. Most of its expcrts would go to neighboring European countries, and about $56 \mathrm{MBD}$ of the $159 \mathrm{MBD}$ crude oil exports would go to the U.S. Gulf coast. A major portion of the needed Mexican crude oil exports would go to Puerto Rico/Virgin Islands; additional Bolivian crudes would go to U.S. refineries. Bolivian crudes are exported only during the Military Disruption.

Regional Product Exports: Estimates of product exports during the Military Disruption are shown in Table 5. The format of this table is similar to Table 4. Total product exports, unlike crude oil dumanci and exports, would increase during the Military Disruption by $17.6 \%$ compared to the BAU level. Two of the three U.S. regions account for most of this great increase (i.e., 3.7 MMBD or $1083 \%$ of $\mathrm{BAU}$ ) in product exports. Most of these product exports went to Europe, where need for imports were triggered by the shortage of crudes for its refineries. According to PAL Model calculations, the following product mix needs to be provided by the U.S. in order for Europe to satisfy its demand during the disruption: liquid gases: $1.3 \mathrm{MMBD}^{7}$; gasoline: $0.7 \mathrm{MMBD}$; distillate: 0.5MMBD; and residual fuel: 0.3 MMBD. The increased jet fuel demand during the disruption can be met as long as additional supplies of crude are available to European refineries.

\footnotetext{
${ }^{7}$ It is very unlikely that the U.j. could be able to transport $1.3 \mathrm{MMBD}$ of liquid gases to Europe. (Exports of liquid gases in 1988 amounted to 48 MBD.) There would be logistical problems as well as safety problems in handling large quantities of liquid gases.
} 


\begin{tabular}{|c|c|c|c|c|c|c|}
\hline \multirow[b]{2}{*}{$\begin{array}{l}\text { Regions } \\
\text { (with PAL Designations) }\end{array}$} & \multirow[b]{2}{*}{$\mathrm{BAU}$} & \multicolumn{3}{|c|}{ Military Disruption } & \multicolumn{2}{|c|}{$\begin{array}{c}\text { \% Chempe in Mritery Dieruption } \\
\text { Rethive to BMU }\end{array}$} \\
\hline & & $\begin{array}{c}\text { Input Value } \\
\text { Reflecting Freo } \\
\text { Martet }\end{array}$ & $\begin{array}{l}\text { Change 'o Have } \\
\text { r poly In } \\
\text { Equilibrium With } \\
\text { Demand }\end{array}$ & \%omer & 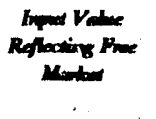 & 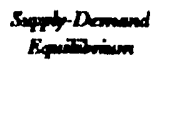 \\
\hline \multicolumn{7}{|l|}{ East Const } \\
\hline \multicolumn{7}{|l|}{ Gulf Coast } \\
\hline \multicolumn{7}{|l|}{ West Coast } \\
\hline United States & 0 & 0 & & & aon & $0,0 \%$ \\
\hline Puerto Rico/Virgin lslands (U) & 0 & 0 & & & aos & $20 \times 6$ \\
\hline Canada (C) & 111 & 115 & -8 & $-1.0 \%$ & 365 & $-36 \%$ \\
\hline Japan $(\mathrm{J})$ & 0 & 0 & & & $\operatorname{aos}$ & $20 \%$ \\
\hline AustraliaNew Zeuland (A) & 0 & 0 & & & $\operatorname{acos}$ & $a 0 x$ \\
\hline Scandinavia (1) & 885 & 0 & 159 & & $-1000 \%$ & - $20 \%$ \\
\hline Unt: 1..̈ngdom/reland (2) & 976 & 90 & 1 & $1.1 \%$ & $-\sin$ & $-90 \%$ \\
\hline Benelux/Denenark (3) & 0 & 0 & & & $a 0 \%$ & $a 0 x$ \\
\hline West Germany (4) & 0 & 0 & & & $a 0 x$ & $a 0 \%$ \\
\hline France (5) & 0 & 0 & & & $0.0 \%$ & $0.0 \%$ \\
\hline Austria/Switzerland (6) & 0 & 0 & & & $a 0 x$ & $0.0 \%$ \\
\hline Spain/Portugal $(\gamma)$ & 0 & 0 & & & ans & $0.0 \%$ \\
\hline Itaty $(8)$ & 0 & 0 & & & $\operatorname{acx}$ & $20 \%$ \\
\hline Gireecé'Turkey (9) & 0 & 0 & & & $20 \%$ & $20 \%$ \\
\hline Venezuela/Ecuador (V) & 730 & 677 & .46 & $-60 \%$ & $-7.3 \%$ & $-13.6 \%$ \\
\hline Litya/Algeria (L) & 2458 & 4 & & & $-990 \%$ & $-99.8 \%$ \\
\hline Nigeria/Gabon $(N)$ & 1555 & 1224 & .317 & $-25.9 \%$ & $-213 \%$ & $-11.7 \%$ \\
\hline Indonesia (1) & 293 & 713 & .70 & $-28 \%$ & $.101 \%$ & $-189 \%$ \\
\hline $\operatorname{Iran}(R)$ & 2391 & 0 & 2 & & $-100.0 \%$ & $-99.9 \%$ \\
\hline Persian Giulf (P) & 11742 & 0 & & & -10000 & $-1000 \%$ \\
\hline Caribbean ( $K$ ) & 212 & 185 & .126 & $41 \%$ & $-127 \%$ & $-722 \%$ \\
\hline $\operatorname{Mexico}(M)$ & 1864 & 1688 & 61 & $36 x$ & $-24 \times$ & $62 \%$ \\
\hline Bolivia/Peru (B) & 0 & 231 & 80 & $346 \times$ & NA & N/A \\
\hline EgypuSyria/Bahrain (Q) & 446 & 490 & .41 & $-9.0 \%$ & $29 x$ & 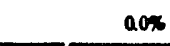 \\
\hline Ange'a/Congo/7aire $(O)$ & 265 & 289 & -1 & $-0.3 \times$ & $2.1 \%$ & $87 \%$ \\
\hline Asian Exporters (Y) & 535 & 717 & .208 & $-29.0 \%$ & 300 & $-19 \%$ \\
\hline Other Latin America (S) & 0 & 0 & & & $a 0 \%$ & aox \\
\hline Oher Africa (i) & 0 & 0 & & & aom & $0.0 \%$ \\
\hline Other Asia (X) & 0 & 0 & & & $a 0 x$ & $a 0 \%$ \\
\hline TOTAL & 24963 & 642.3 & .517 & $80 \%$ & $-743 \%$ & $-X_{2} .3$ \\
\hline
\end{tabular}




\begin{tabular}{|c|c|c|c|c|c|c|}
\hline \multirow{2}{*}{$\begin{array}{l}\text { Regions } \\
\text { (with PAL, Designations) }\end{array}$} & \multirow[b]{2}{*}{ BAU } & \multicolumn{3}{|c|}{ Military Disruption } & \multicolumn{2}{|c|}{ 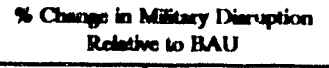 } \\
\hline & & $\begin{array}{l}\text { Input Value } \\
\text { Reflecting Free } \\
\text { Market }\end{array}$ & $\begin{array}{l}\text { Change To Hiave } \\
\text { Supph In } \\
\text { Equilibrium With } \\
\text { Demand }\end{array}$ & $x$ andre & 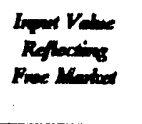 & Shrot-Danend \\
\hline East Coast & 9 & 6 & 3 & saces & $-303 \pi$ & aox \\
\hline Gulf Cosurt & 181 & 1213 & 2297 & 10046 & $5702 \%$ & $1809.2 \%$ \\
\hline West Cosat & 243 & 210 & 139;. & $\cos 3 x$ & $-136 \%$ & $5527 \%$ \\
\hline United States & 433 & 1429 & 3693 & 25245 & $23 a 0 x$ & $10029 \times$ \\
\hline Puerto Rico/Virgin lalands (U) & 288 & 289 & 67 & $202 x$ & $a .3 \%$ & $236 \%$ \\
\hline Canada (C) & 282 & 259 & & & $82 \pi$ & $82 \%$ \\
\hline Japan (J) & 59 & 22 & 36 & $16 a c x$ & $27 \%$ & $-1.7 \%$ \\
\hline Australia/New Zealand (A) & 84 & 76 & & & 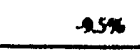 & $-5 \%$ \\
\hline Scandinavia (1) & 160 & 122 & 128 & $105.6 x$ & $-2020 \%$ & +5633 \\
\hline United Kingdom//reland (2) & 404 & 312 & & & -2ans & $-228 \pi$ \\
\hline Benelux/Denmart (3) & 1334 & 1024 & .197 & $-122 \%$ & $-232 \%$ & $-380 \%$ \\
\hline West Germany (4) & 136 & 104 & & & $-225 \%$ & $-23.5 \%$ \\
\hline France (s) & 240 & 184 & .184 & $-1000 \%$ & $-233 \pi$ & $-1000 \%$ \\
\hline Austria/Swiuertand ( $\delta$ ) & 59 & 45 & -1 & $-22 \times$ & $-227 \%$ & .25 .47 \\
\hline Spain/Portugal (7) & 202 & 154 & .110 & -71.45 & $-2010 \%$ & $-782 \times$ \\
\hline Italy (8) & 241 & 183 & & & $-2 A 1 \%$ & $-24.1 \%$ \\
\hline Greece/Turtey (9) & 78 & 59 & & & $-24.4 x$ & $-21.4 \times$ \\
\hline Venezuela/Ecuador (V) & 1423 & 1075 & & & $-2215 x$ & $-205 \%$ \\
\hline 1.jbya/Algeria (L) & 0 & 0 & & & $20 x$ & aox \\
\hline Nigeria/Gabon $(\mathrm{N})$ & 0 & 0 & & & $20 \%$ & aos \\
\hline Indonesia (I) & 0 & 0 & & & $a 0 x$ & a.0\% \\
\hline $\operatorname{Iran}(R)$ & 18 & 0 & & & $a 0 x$ & $-1000 \%$ \\
\hline Persian Gulf (P) & 1204 & 0 & & & aon & $-1000 \%$ \\
\hline Caribbean (K) & 283 & 248 & 100 & $11.1 \%$ & $-124 \%$ & $207 \%$ \\
\hline Mexico (M) & 135 & 129 & & & $14 m$ & $14 x$ \\
\hline Bolivia/Peru (B) & 0 & 0 & & & $\cos x$ & $00 \%$ \\
\hline Egype/Syria/Bahrain (Q) & 0 & 0 & & & $20 x$ & $0.0 \%$ \\
\hline Angola/Congo/Zaire $(O)$ & 0 & 0 & & & aom & $a 0 \pi$ \\
\hline Asian Exporters ( $Y$ ) & 790 & 114 & .114 & $-1000 \%$ & $-85.6 \%$ & $-1000 x$ \\
\hline Oiher Latin America (S) & 0 & 0 & & & $a, \infty$ & aox \\
\hline Other Africa (F) & 0 & 0 & & & $a 0 x$ & $\operatorname{aos}$ \\
\hline Other Asia (X) & 0 & 0 & & & $a 0 x$ & acos \\
\hline TOTAL. & 7853 & 5828 & 3419 & $587 \%$ & $-252.0 \times$, & $17.6 \%$ \\
\hline
\end{tabular}


Four other regions where product exports had to be increased from their free-market levels were: Puerto Rico/Virgin Islands, Caribbean, Japan, and Scandinavia. The maximum increase (i.e., $128 \mathrm{MBD}$ ) in product exports occurred in Scandinavia, most of it going to its neighboring countries. The Caribbean exports increased mostly in gasoline and other products, all of which went to the U.S. East Coast. Similarly, increased exports of residual fuel from Puerto Rico/Virgin Islands were needed to satisfy the U.S. East Coast demand.

France and Asian Exporters would no longer be product exporters during the Military Disruption. In Spain/Portugal the reduction in product exports would be comparatively less severe, $22.8 \%$ of its BAU level.

${ }^{8}$ Recall that Scandinavia also had rationing. 


\section{CONCLUSIONS}

This report studied the impacts of an extreme worst-case military confrontation on petroleum availability. Under such a disruption, supply and demand would significantly decline -- by over 20 MMBD. Furthermore, the likelihood of naval hostilities means that ocean-going flows of both crude oil and products would also be greatly reduced. Under such a scenario, there would be large imbalances in supply and demand. Unlike previous studies involving oil market models, this study found that the available supply would not meet demand, even taking into account the greatly reduced civilian demand that would react to extremely high prices.

The problem of imbalances can only be solved by extraordinary actions, outside of normal economic markets. ${ }^{9}$ These actions take the form of rationing, and military actions to ensure the additional flow of crudes and products.

In particular, from Table 3, reductions in demand in the form of rationing could be expected on the U.S. West Coast, Scandinavia, Venezuela, Asian Exporters and Iran (though it may be difficult to envision the circumstances where Iran would unilaterally impose rationing).

Additional sources of supply would also have to be found to meet European demand. One major problem is in ensuring the safe passage of crude, from the Norwegian North Sea to European refineries, and especially the safe passage of products from the U.S. and Norway (refer to Table 4). Great quantities of liquid gases, gasoline, distillates, and residual fuel would be needed from both the U. S. Gulf Coast and East Coast -- a total of 2.8 MMBD. There would be logistical transportation problems as well. Major military support would be required to protect tankers from hostile actions. The military would then have to consider the trade-offs in allocating resources to protect tanker flows as opposed to other needs.

This intuitive conclusion is an outcome of the modeling and analysis, rather than an assumption or a simple statement, and has heretofore not been observed in previous modeling exercises. 


\section{IMPLICATIONS FOR THE NAVY}

The results and conclusions of this study could have several implications for the Navy:

(1) The results in Table 4 suggest that the Navy may wish to plan for extensive engagements in the North Atlantic and North Sea to protect the important flows of products and crude oil destined for Europe from the North Sea region and from the U.S.

(2) If oil exports from the Persian Gulf region are assumed to be lost, then from the standpoint of petroleum flows, the Mediterranean Sea appears to be less critical than the North Atlantic or North Sea. The results in Table 4 highlight the key flows that need to be protected in order to meet European demand.

(3) The Navy may wish to pay special attention to pre-positioning product stocks, because needed fuels may be unavailable in the European theater (again, refer to Table 4 and Sect. 3).

(4) Because of possible fuel availability problems, a flexible-fuel strategy may be worthwhile in terms of affording the Navy maximum flexibility in its mobility activities. The modeling results show that, in general, fuel shortages may develop under a worst-case scenario. Having the option to use al chative fuel sources would make the Navy less dependent on specialized fuels that are availdole from a limited number of refiners or that may be intercepted in transit to the theater. Any major changes in fuel specifications or flexible-fuel policies will also require more intensive research to improve, or at least maintain, engine performance.

These implications all are preliminary and deserve further study. 


\section{REFERENCES}

Buck, P.B. et al. (1973) Supply and Distribution of POL to Tactical Forces (U). WSEG Report 204, Arlington, Virginia: Institute for Defense Analyses, Systems Evaluation Division.

Curlee, T.R. (1982) The Impacts of Oil Disturbances: Lessons from Experience. ORNL/TM-8492, Oak Ridge, Tennessee: Oak Ridge National Laboratory.

Curlee, T.R., Reister, D.B. (1989) Oil Vulnerability and Intermediate Price Fluctuations: A Preliminary Assessment and Proposal. ORNL/TM-11155. Oak Ridge, Tennessee: Oak Ridge Natiunal Laboratory.

Curlee, T.R., Turhollow, A., Das, S. (1988) Oil vulnerability and modeling methodologies, Energy Economics, 9: 3-16.

Cutler, T. (1985) The military demand for oil, Petroleum Economist, August 1985, 279-284.

Cutler, T. (1986a) The role of petroleum in wartime, Petroleum Economist, April 1986, 137-142.

Cutler, T. (1986b) Vulnerability of sea transportation, Petroleum Economist, October 1986, 370-373.

Cutler, 'T. (1987) Strategic significance of jet fuel - Part I, Petroleum Economist, May 1987, 161-164.

Das, S., Hadder, G.R., Davis, R.M., Lee, R. (1988a) Petroleum availability in disrupted markets, Resources Policy, 14:173-180.

Das, S., Hadder, G.R., Leiby, P.N., Davis, R.M., Lee, R. (1988b) Navy Mobility Fuels Forecasting System, Phase IV Report. ORNL-6517. Oak Ridge, Tennessee: Oak Ridge National Laboratory.

DeMouy, L. D. (1988) Data tabulated by Louis D. DeMouy, Chief of the International Statistics Branch, International and Contingency Information Division, Energy Information Administration, U.S. Department of Energy.

Department of Defense (DoD) (1982) Defense Energy Information System, DoD 5126.46-M, Office of the Assistant Secretary of Defense, Manpower, Reserve Affairs and Logistics, Washington, DC. December.

Energy Information Administration, U.S. Department of Energy (1987) International Energy Annual 1986. DOE/EIA-0219(86), Washington, DC. pp. 32-33.

Energy Information Administration, U.S. Department of Energy (1989) International Energy Outlook 1989. DOE/EIA-0484(89), Washington, DC.

Hadder, G. R., Das, S., Leiby, P. N., Lee, R., Davis, R. M. (1989) Navy fuel production during a Middle East political disruption, Energy, 14:965-966. 
Hadder, G.R., Das, S., Davis, R.M., Lee, R. (1988a) Navy jet fuel production during a military mobilization scenario, Energy. 13:537-542.

Hadder, G.R., Das, S., Davis, R. M., Lee, R. (1988b) Navy jet fuel production: strategies for Persian Gulf crisis, Energy Policy. 17:235-243.

Horwich, G., Weimer, D.L. (198 b) Oil Price Shocks, Market Response, and Contingency Planning. Washington, DC: American Enterprise Institute for Public Policy Research.

Horwich, G., Weimer, D.L. (1988) Responding to Internationai Oil Crises. Washington, DC: American Enterprise Institute for Public Policy Research.

Leiby, P.N., I ee, R. (1988) Preliminary Results of the SPR Size Cost-Benefit Study. ORNL-6563. Oak Ridge, Tennessee: Oak Ridge National Laboratory.

Mawn, P.E. (1988) Allied peacetime military needs. CRA No. 210.01. Memorandum from Paul E. Mawn to Jerry Hadder. Charles River Associates. February 26, 1988.

Office of the Assistant Secretary of Defense (Manpower, Reserve Affairs and Logistics), U.S. Department of Defense (1982) Defense Energy Information System. DoD 5126.46-M. Washington, DC.

Reister, D.B. (1987) A Compact Model of Oil Supply Disruptions. ORNL/TM-10519. Oak Ridge, Tennessee: Oak Ridge National Laboratory.

U.S. Department of Energy (1987) Energy Security. DOE/S-0057, Washingion, DC.

U.S. Department of Energy (1989) Repcat to the Congress on Expansion of the Strategic Petroleum Reserve to One Billion Barrels, DOE/FE-0126, Assistant Secretary, Fossil Energy, April. 


\section{APPENDIX}

\begin{tabular}{||l|l||}
\hline \multicolumn{2}{|c|}{$\begin{array}{c}\text { Regions } \\
\text { (with PAL Designations) }\end{array}$} \\
\hline \hline East Coast (E) & List of Countries \\
\hline Gulf Coast (G) & U.S. PADD 2A/2B/3/4 \\
\hline West Cuast (W) & Alaska N. Slope, U.S. PADD 5 \\
\hline Puerto Rico/V.I. (U) & Puerto Rico, Virgin Islands \\
\hline Canada (C) & Canada \\
\hline Japan (J) & Japan \\
\hline Australia/New Zealand (A) & Australia, New Zealand \\
\hline Scandinavia (1) & Finland, Iceland, Norway, Sweden \\
\hline United Kingdom/Ireland (2) & Ireland, United Kingdom \\
\hline Benelux/Denmark (3) & Belgium, Denmark, Luxemburg, Netherlands \\
\hline West Germany (4) & West Germany \\
\hline France (5) & France \\
\hline Austria/Switzerland (6) & Austria, Switzerland \\
\hline Spain/Portugal (7) & Portugal, Spain \\
\hline Italy (8) & Italy \\
\hline Greece/Turkey (9) & Greece, Turkey \\
\hline Venezuela/Ecuador (V) & Ecuador, Venezuela \\
\hline Libya/Algeria (L) & Algeria, Libya \\
\hline Nigeria/Gabon (H) & Gabon, Nigeria \\
\hline Indonesia (I) & Indonesia \\
\hline Iran (R) & Iran \\
\hline Persian Gulf (P) & $\begin{array}{l}\text { Iraq, Kuwait, Neutral Zone, Qatar, Saudi } \\
\text { Arabia, United Arab Emirates }\end{array}$ \\
\hline Caribbean (K) & Bahamas, Netherlands Antilles, Trinidad \\
\hline Mexico (M) & Mexico \\
\hline
\end{tabular}




\begin{tabular}{|c|c|}
\hline Bolivia/Peru (B) & Bolivia, Peru \\
\hline Egypt/Syria/Bahrain (Q) & $\begin{array}{l}\text { Egypt, Syrian Arab Republic, Tunisia, } \\
\text { Bahrain }\end{array}$ \\
\hline Angola/Congo/Zaire (O) & Angola, Congo, Zaire \\
\hline Asian Exporters ( $Y$ ) & Brunei, Malaysia, Singapore, Oman \\
\hline Other Latin America (S) & $\begin{array}{l}\text { Antarctica, Antigua-Leew. Island, Argentina, } \\
\text { Barbados, Belize, Bermuda, Brazil, Caymans } \\
\text { Islands, Chile, Colombia, Costa Rica, Cuba, } \\
\text { Dominican Republic, El Salvador, Falkland } \\
\text { Islands, Greenland, Guadalupe, Guatemala, } \\
\text { Guiana, Guyana, Haiti, Honduras, Jamaica, } \\
\text { Martinique, Nicaragua, Panama Canal, } \\
\text { Panama, Paraguay, St. Pierre, Surinam, } \\
\text { Uruguay, Windward Island }\end{array}$ \\
\hline Other Africa (F) & $\begin{array}{l}\text { Burundi, Cape Verde, Central Africa } \\
\text { Republic, Chad, Comoro Islands, Cyprus, } \\
\text { Dahomey, Equatorial Guinea, Ethiopia, } \\
\text { Faeroe Island, Former West Africa, Former } \\
\text { Equatorial Africa, Gambia, Ghana, Gibraltar, } \\
\text { Guinea Bissau, Istael, Ivory Coast, Jordan, } \\
\text { Kenya, Lebanon, Liberia, Madagascar, } \\
\text { Malawi, Mali, Malta, Mauritania, Mauritius, } \\
\text { Morocco, Mozambique, Niger, Republic of } \\
\text { Guinea, Reunion, Zimbabwe, Rwanda, Sao } \\
\text { Tome de Principe Islands, Senegal, } \\
\text { Seychelles, Sierra Leone, Somalia, South } \\
\text { Africa, Sudan, Tanganyika, Tanzania, Togo, } \\
\text { Uganda, United Republic Cameroon, Upper } \\
\text { Volta, Zambia, Zanzibar }\end{array}$ \\
\hline Other Asia (X) & $\begin{array}{l}\text { Afghanistan, Bangladesh, British Solomon } \\
\text { Islands, Burma, Cambodia, Christmas Island, } \\
\text { Fiji, Gibraltar Island, Guam, Hong Kong, } \\
\text { India, Khmer Republic, Korea Republic, } \\
\text { Laos, Macau, Malagasy Republic, Nauru, } \\
\text { Nepal, New Caladonia, New Hebrides, North } \\
\text { Borneo, Okinawa, Pacific Islands, Pakistan, } \\
\text { Papua New Guinea, Philippines, Port Timor, } \\
\text { Samoa, Sarawak, Sri Lanka, Taiwan, } \\
\text { Thailand, Wake Island, Yemen }\end{array}$ \\
\hline
\end{tabular}



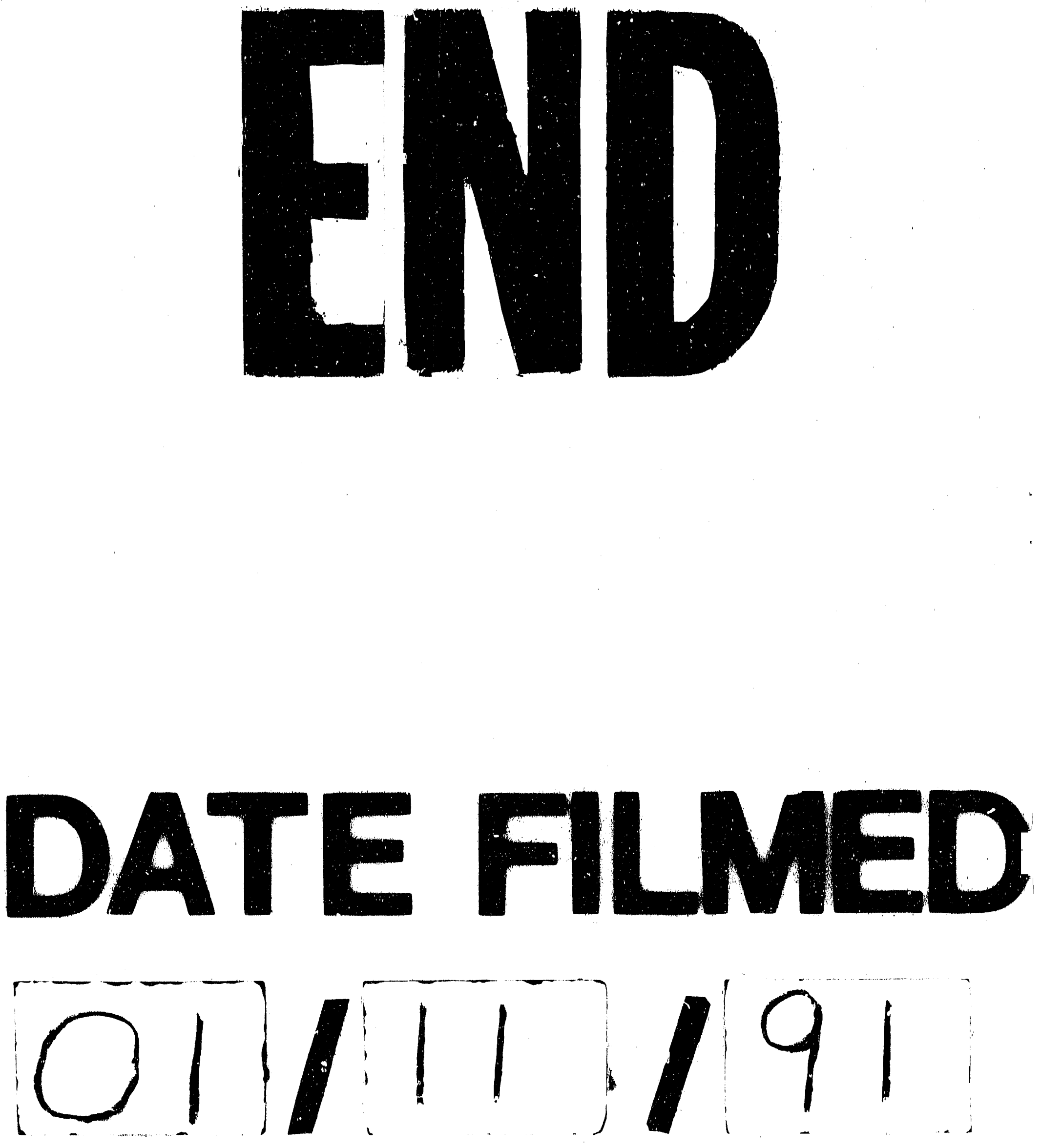
